\title{
Potentiometric Flow Injection Analysis of Glucose Using Hexacyanoferrate(III)-Hexacyanoferrate(II) Potential Buffer
}

\author{
Hiroki OHURA*, Toshihiko Imato**, Sumio YAMASAKI* and Nobuhiko IshibaShI** \\ *Department of Industrial Chemistry, Faculty of Engineering, Kyushu Sangyo University, \\ Matsugadai, Fukuoka 813 \\ **Department of Applied Analytical Chemistry, Faculty of Engineering, Kyushu University, \\ Hakozaki, Fukuoka 812
}

\begin{abstract}
Flow injection analysis of glucose is described, using a combination of the potentiometric detection with the potential buffer solution consisting of hexacyanoferrate(III)-hexacyanoferrate(II). Effects of the concentration of the potential buffer solution, reaction time and temperature are examined on sensitivity of the proposed analytical method. Glucose from $10^{-7} \mathrm{M}$ to $10^{-3} \mathrm{M}$, for injections of $140 \mu$ l samples, can be determined by changing concentrations of the buffer solution from $1 \times 10^{-5} \mathrm{M}$ to $1 \times 10^{-2} \mathrm{M}$.
\end{abstract}

Keywords Potentiometric flow injection analysis, oxidation-reduction reaction, glucose, hexacyanoferrate(III)hexacyanoferrate(II) buffer solution

A rapid and highly sensitive analysis for glucose has been important in the fields of biochemical, clinical and food analyses. Several papers have been published on enzymatic flow analysis for glucose using either of spectrophotometric', amperometric ${ }^{2}$, chemiluminescent $^{3,4}$ and potentiometric ${ }^{5}$ detections. Llenado and Rechnitz ${ }^{5}$ used a flow-through type iodide ion selective membrane electrode for potentiometric detection in the enzymatic determination of glucose. Diamandis and Hadjiioannou ${ }^{6}$ have determined glucose by monitoring periodate consumed by a reaction with glucose with a periodate ion selective electrode. Porter and Sawyer? and Brunt $^{8}$ have studied determinations of glucose and other reducing carbohydrates based on the changes of redox potentials of a hexacyanoferrate(III) $\left(\left[\mathrm{Fe}(\mathrm{CN})_{6}\right]^{3-}\right)-$ hexacyanoferrate(II)([Fe(CN)6 $\left.{ }^{4-}\right)$ buffer solution due to the reaction of carbohydrates with $\left[\mathrm{Fe}(\mathrm{CN})_{6}\right]^{3-}$. These potentiometric analyses ${ }^{s-8}$ for glucose have been based on the gas-segmented flow technique, which is generally said to be more or less complicate and cumbersome in both an apparatus and an analytical work in comparison with the non-gas segmented flow injection analysis (FIA). 9 Actually, even a simple analysis using a reaction of a sample with a reagent may require a four-channel pump for streams of the sample, reagent, air and debubbling line. The streams have to be debubbled before detection. In the Brunt's paper, bubbles of nitrogen gas were used instead of air bubbles for segmentation of the sample-buffer $\left(\left[\mathrm{Fe}(\mathrm{CN})_{6}\right]^{3-}-\left(\left[\mathrm{Fe}(\mathrm{CN})_{6}\right]^{4-}\right)\right.$ mixture in order to avoid the air-oxidation of the buffer. A lower limit of detection has been reported to be the order of $10^{-5} \mathrm{M}^{8}$
Recently, we reported on the potentiometric flow injection analysis of trace amounts of bromate ${ }^{10}$ and hydrogen peroxide ${ }^{11}$ utilizing reactions with potential buffer solutions containing a redox pair such as iron(III) and iron(II). The FIA method using the potential buffer has following advantages: (1) the electrode potential is excellently stable and reproducible, since the electrode is immersed in a well-defined potential buffer solution, and (2) samples in a wide concentration range are determinable by appropriately selecting a concentration of a buffer solution.

In the present paper, we will report the potentiometric determination of glucose using the FIA technique. The potential buffer solution used consists of mixed solutions of $\left[\mathrm{Fe}(\mathrm{CN})_{6}\right]^{3-}-\left[\mathrm{Fe}(\mathrm{CN})_{6}\right]^{4-}$. The potential change of the buffer solution caused by reduction of $\left[\mathrm{Fe}(\mathrm{CN})_{6}\right]^{3-}$ with glucose is measured with an ORP (oxidation-reduction potential) electrode. Sensitivity of the proposed method is compared with the gassegmented flow methods. ${ }^{7,8}$

\section{Experimental}

\section{Reagents and apparatus}

Standard solutions of glucose were prepared by dissolving $\mathrm{D}(+)$-glucose monohydrate (Kishida Ltd.) in deionized water. The potential buffer solution containing $0.1 \mathrm{M}\left[\mathrm{Fe}(\mathrm{CN})_{6}\right]^{3-}$ and $0.1 \mathrm{M}\left[\mathrm{Fe}(\mathrm{CN})_{6}\right]^{4-}$ was prepared by dissolving potassium hexacyanoferrate(III), potassium hexacyanoferrate(II) (Katayama Ltd.) and sodium hydroxide in deionized water, as the stock 
solution. For the sake of simplicity, this buffer is written as $0.1 \mathrm{M}(1: 1)$ potential buffer. Lower concentrations of buffer solutions were prepared by serial dilutions of the stock solution with deionized water. Distilled and deionized water was used throughout the study.

The FIA apparatus was constructed by using a peristaltic pump (Model Minipuls 2, Gilson Inc.), a 6way valve (HPV6, Gasukuro Kogyo, Co.) with a loop for sample injection, a flow-through type ORP electrode detector cell (Model FLC-11, Denki Kagaku Keiki, Co.,(DKK) and teflon tubings. The detector consists of an ORP electrode (platinum electrode) and a silver/ silver chloride reference electrode, which were fixed to the body of the flow cell. ${ }^{12}$ Potential difference between two electrodes was measured with a potentiometer [Model IOC-10 (DKK)], and signals were fed to a recorder (Model EPR221E, Toa Electronics Ltd.).

\section{Procedure}

The FIA system used is shown in Fig. 1. A potential buffer solution consisting of a mixture of $\left[\mathrm{Fe}(\mathrm{CN})_{6}\right]^{3-}$ $\left[\mathrm{Fe}(\mathrm{CN})_{6}\right]^{4-}$ was pumped through the reagent channel (R.S.), while a water stream was pumped through the carrier channel (C.S.). A sample solution injected into the carrier stream was merged with the stream of the potential buffer solution at a confluence point $C$, and the mixture was allowed to pass through the reaction coil (R.C.) and the cooling coil (C.C.). The reaction of a sample with $\left[\mathrm{Fe}(\mathrm{CN})_{6}\right]^{3-}$ gives rise to a change in composition of the redox pair in the buffer solution. The potential change was detected with the ORP electrode (D) located downstream and was recorded as a peak-shaped signal. The concentration of glucose was determined based on a peak height.

The standard operational parameters for glucose analysis are given in Fig. 1, which were decided based on preliminary experiments. The sample solution $(140 \mu 1)$ was injected usually at a time interval of $3 \mathrm{~min}$. It took about $4.2 \mathrm{~min}$ from a sample injection to detection of a peak maximum. The average residence time of the

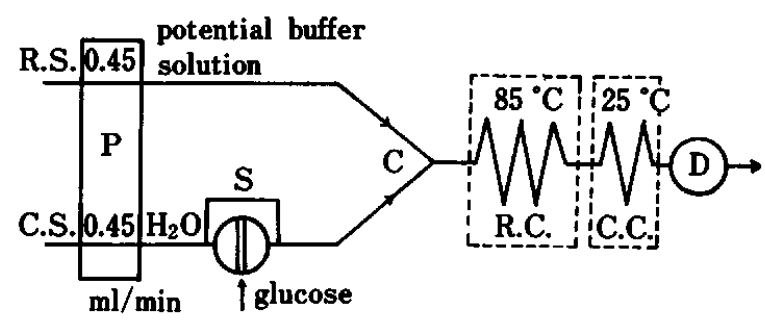

Fig. 1 Schematic diagram for flow injection analysis for glucose. C.S., Stream of carrier (water); R.S., Stream of potential buffer solution consisting of $\left[\mathrm{Fe}(\mathrm{CN})_{6}\right]^{3-}-[\mathrm{Fe}-$ $\left.(\mathrm{CN})_{6}\right]^{4-}$ containing $0.6 \mathrm{M} \mathrm{NaOH}$; $\mathrm{P}$, peristaltic pump; $\mathrm{S}$, sample injector (sample volume, $140 \mu$ l); R.C., reaction coil (12 m $\times 0.5 \mathrm{~mm}$ i.d.); C.C., cooling coil (4 m×0.5 mm i.d.); Length of tube between $S$ and $C, 50 \mathrm{~cm} \times 0.5 \mathrm{~mm}$ i.d.; D, ORP electrode; C, confluence point sample in the reaction coil ( i.e. reaction time) was about $2.5 \mathrm{~min}$.

\section{Analytical Method}

According to Nath et al. ${ }^{13}$, the overall reaction between glucose and $\left[\mathrm{Fe}(\mathrm{CN})_{6}\right]^{3-}$ is expressed by the following formula(1);

$$
\begin{aligned}
& \text { glucose }+n\left[\mathrm{Fe}(\mathrm{CN})_{6}\right]^{3-} \stackrel{\mathrm{OH}^{-}}{\longrightarrow} \\
& n\left[\mathrm{Fe}(\mathrm{CN})_{6}\right]^{4-}+\text { other products }
\end{aligned}
$$

where $n$ is the number of moles of $\left[\mathrm{Fe}(\mathrm{CN})_{6}\right]^{3-}$ required to oxidize a mole of glucose, and other products were reported to be gluconic and glucanic acids. ${ }^{14}$

When the reaction of glucose with the potential buffer solution completes according to the reaction formula(1), the potential change $(\Delta E)$ of the ORP electrode is expressed as follows from Nernst equation.

$$
\Delta E=-59 \log \frac{1-n[\text { glucose }]_{0} /\left\{\left[\mathrm{Fe}(\mathrm{CN})_{6}\right]^{3-}\right\}_{0}}{1+n[\text { glucose }]_{0} /\left\{\left[\mathrm{Fe}(\mathrm{CN})_{6}\right]^{4-}\right\}_{0}},(\mathrm{mV})
$$

where [glucose $]_{0},\left\{\left[\mathrm{Fe}(\mathrm{CN})_{6}\right]^{3-}\right\}_{0}$ and $\left\{\left[\mathrm{Fe}(\mathrm{CN})_{6}\right]^{4-}\right\}_{0}$ are initial concentrations of corresponding glucose, $[\mathrm{Fe}-$ $\left.(\mathrm{CN})_{6}\right]^{3-}$ and $\left[\mathrm{Fe}(\mathrm{CN})_{6}\right]^{4-}$, respectively.

\section{Results and Discussion}

\section{Determination of standard analytical procedure}

(A) Concentration of sodium hydroxide in the potential buffer solution and reaction temperature

Effects of the concentration of sodium hydroxide in the potential buffer and reaction temperature on the potential change (peak height) were examined for cases using $5 \times 10^{-5} \mathrm{M}(1: 1)$ potential buffer. A $140 \mu \mathrm{l}$ of $2.5 \times 10^{-6} \mathrm{M}$ sample was injected. No peak was detected for the sodium hydroxide concentration below $0.05 \mathrm{M}$. The peak height increased with the increase of the concentration of sodium hydroxide, but it remained almost constant in the concentration range of from 0.6 $\mathrm{M}$ to $1 \mathrm{M}$.

No peak was observed when temperature of the reaction coil was below $40^{\circ} \mathrm{C}$. The peak could be observed above about $50^{\circ} \mathrm{C}$, and its height approached a constant value over about $80^{\circ} \mathrm{C}$. Thus, $0.6 \mathrm{M}$ sodium hydroxide and reaction temperature of $85^{\circ} \mathrm{C}$ were chosen for the standard procedure of analysis.

(B) Response of the ORP electrode for the reaction of glucose with the potential buffer solution.

The reactivity of glucose against $\left[\mathrm{Fe}(\mathrm{CN})_{6}\right]^{3-}$ in the potential buffer was examined by using the FIA system shown in Fig. 1. The FIA peak height is dependent on a degree of dispersion of a sample flowing through the tube as well as on the progress of the reaction. In order to observe a change of a peak height due to the progress 
of the reaction only, the potential change has to be measured for the sample under the condition that no essential dispersion takes place. This may be achieved by injecting a sufficiently large volume of the sample, and observing the potential at the center of the sample band, i.e., the plateau potential, which considered to be free from dispersion. To obtain such a situation, $1.66 \mathrm{ml}$ of sample solutions were injected into the carrier stream. Figure 2 represents a variation of observed plateau potentials against reaction times, i.e., mean residence times of the sample in the reaction coil. When concentrations of potential buffers were in the range from $1 \times 10^{-2} \mathrm{M}(1: 1)$ to $5 \times 10^{-5} \mathrm{M}(1: 1)$, response potentials gradually increased with increasing reaction time until about $2.5 \mathrm{~min}$ (corresponding to a flow rate of $0.45 \mathrm{~cm}^{3} \mathrm{~min}^{-1}$ ) and then reached almost constant values (equilibrium potentials), although heights of plateau potentials still continued to increase as the case of $1 \times 10^{-5} \mathrm{M}(1: 1)$ buffer showed. This indicates that the reaction between glucose and $\left[\mathrm{Fe}(\mathrm{CN})_{6}\right]^{3-}$ completes in about $2.5 \mathrm{~min}$, except for the case of very dilute buffer solution. Therefore, the response potential after a reaction of $2.5 \mathrm{~min}$ was measured as a standard procedure of analysis.

Table 1 (A) lists observed response potentials $(\Delta E)$ after the reaction time of $2.5 \mathrm{~min}$ and $n$ values calculated from the equation (2). It can be seen from

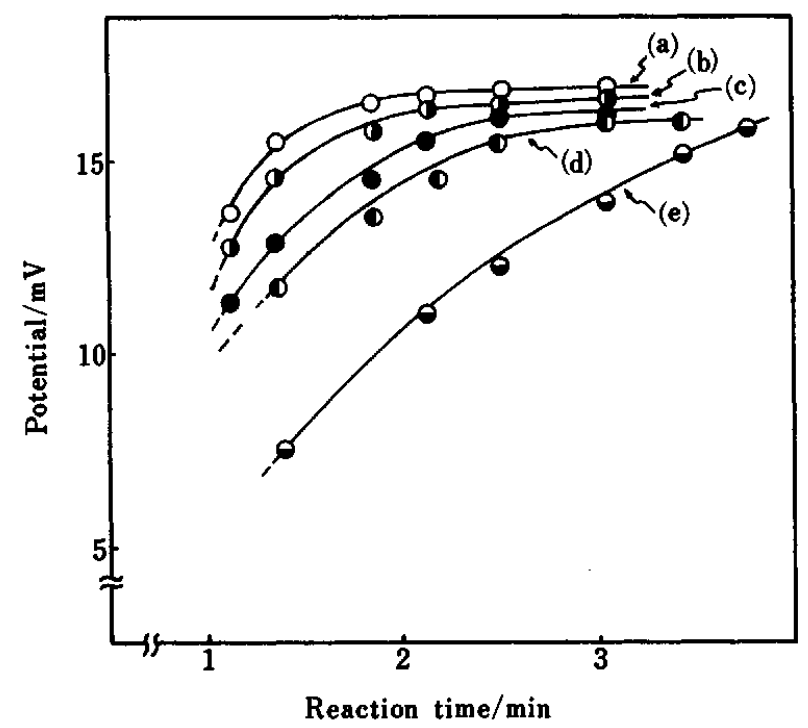

Fig. 2 Effect of reaction time on response potential.

Concentration* (sample, potential buffer solution) (a): (5× $\left.10^{-4} \mathrm{M}, 1 \times 10^{-2} \mathrm{M}\right)$; (b): $\left(5 \times 10^{-5} \mathrm{M}, 1 \times 10^{-3} \mathrm{M}\right)$; (c): $\left(5 \times 10^{-6}\right.$ $\left.\mathrm{M}, 1 \times 10^{-4} \mathrm{M}\right)$; (d): $\left(2.5 \times 10^{-6} \mathrm{M}, 5 \times 10^{-5} \mathrm{M}\right) ;(\mathrm{e}): 5 \times 10^{-7} \mathrm{M}$, $1 \times 10^{-5} \mathrm{M}$ ). *Sample concentrations are one twentieth of those of potential buffer solutions. Volume of samples injected: $1.66 \mathrm{ml}$. Concentration of sodium hydroxide in the buffer solutions: $0.6 \mathrm{M}$. The reaction time is calculated from dimensions (length and diameter) of reaction coils, and flow rates of C.S. and R.S. are in the range from 0.31 to $1.03 \mathrm{~cm}^{3} \mathrm{~min}^{-1}$. The other experimental conditions are the same as those in Fig. 1.
Table 1(A) that $6 \mathrm{~mol}$ of $\left[\mathrm{Fe}(\mathrm{CN})_{6}\right]^{3-}$ are consumed for oxidation of $1 \mathrm{~mol}$ of glucose under reaction conditions shown in Fig. 1. This $n$ value is slightly different from Brunt's values ${ }^{8}$ ( 4 to $5 \mathrm{~mol}$ ) obtained under different reaction conditions, i.e., the reaction temperature of $90^{\circ} \mathrm{C}$ and the presence of $0.1 \mathrm{M}$ sodium hydroxide in the buffer solution.

\section{Sensitivity and concentration of the buffer solution}

Equation(2) predicts that the calibration curve between concentrations of glucose and potentials is approximately linear as long as the concentration of glucose is lower than $6 \%$ against that of hexacyanoferrate, when the value of $n$ is 6 and the molar ratio of $\left[\mathrm{Fe}(\mathrm{CN})_{6}\right]^{3-} /\left[\mathrm{Fe}(\mathrm{CN})_{6}\right]^{4-}$ is unity. For the case of the ratio of [glucose]/[Fe(CN) $]^{3-}$ below $6 \%$, the deviation from linearlity is calculated to be less than $2.5 \%$. A degree of dispersion is observed to be about one third for $140 \mu \mathrm{l}$ sample under the standard procedure of analysis described. Therefore, samples of concentrations up to about $20 \%$ compared to a hexacyanoferrate(III) concentration may be expected to have a linear calibration curve on peak heights. In fact, linear relations were observed for FIA of $1 \times 10^{-4} \mathrm{M}$ to $2 \times 10^{-3}$ $M$ glucose using $1 \times 10^{-2} \mathrm{M}(1: 1)$ buffer and for FIA of $2.5 \times 10^{-7} \mathrm{M}$ to $2.5 \times 10^{-6} \mathrm{M}$ glucose using $1 \times 10^{-5} \mathrm{M}(1: 1)$ buffer, as shown in Fig. 3(A). Table 1(B) lists sensitivity values $(\mathrm{mV} / \mathrm{mM})$, i.e., slopes of calibration curves under various concentrations of buffer solutions. Sensitivities are in an inverse proportion to concentrations of buffer solutions.

\section{Limit of detection}

As described above, sensitivity $(\mathrm{mV} / \mathrm{mM})$ increases with decreasing concentration of buffer solutions. Sensitivity and its reproducibility for low levels of glucose were thus examined for cases using low concentrations of buffer solutions consising of $1 \times 10^{-5}$ $M(1: 1), 1 \times 10^{-5} \mathrm{M}(1: 0.1)$ and $5 \times 10^{-6} \mathrm{M}(1: 1)$. The results are shown in Fig. 3. Sample solutions were

Table 1 Effect of concentration of potential buffer solution on $n$ value and sensitivity

\begin{tabular}{|c|c|c|c|}
\hline \multirow{2}{*}{$\begin{array}{c}\text { Concentration } \\
\text { of the buffer/ } \\
\mathbf{M}\end{array}$} & \multicolumn{2}{|c|}{ (A) } & \multirow{2}{*}{ 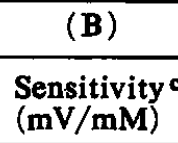 } \\
\hline & $\begin{array}{c}\Delta E^{\mathbf{a}} \\
(\mathbf{m V})\end{array}$ & $n^{b}$ & \\
\hline $1 \times 10^{-2}$ & 16.7 & 6.3 & 9.7 \\
\hline $1 \times 10^{-3}$ & 16.5 & 6.2 & $9.5 \times 10$ \\
\hline $1 \times 10^{-4}$ & 16.3 & 6.1 & $9.4 \times 10^{2}$ \\
\hline $5 \times 10^{-5}$ & 15.5 & 5.9 & $1.9 \times 10^{3}$ \\
\hline $1 \times 10^{-5}$ & 12.3 & - & $6.2 \times 10^{3}$ \\
\hline
\end{tabular}

a. $\Delta E$ 's are response potentials at the reaction time of $2.5 \mathrm{~min}$, shown in Fig. 2.

b. $n$ : number of moles of $\left[\mathrm{Fe}(\mathrm{CN})_{6}\right]^{3-}$ consumed for oxidation of a mole of glucose.

c. Sensitivity: slope of calibration curve (peak height/ $\mathrm{mV}$ obtained by injection of $1 \mathrm{mM}$ glucose). Sample volume: $140 \mu$ l. 

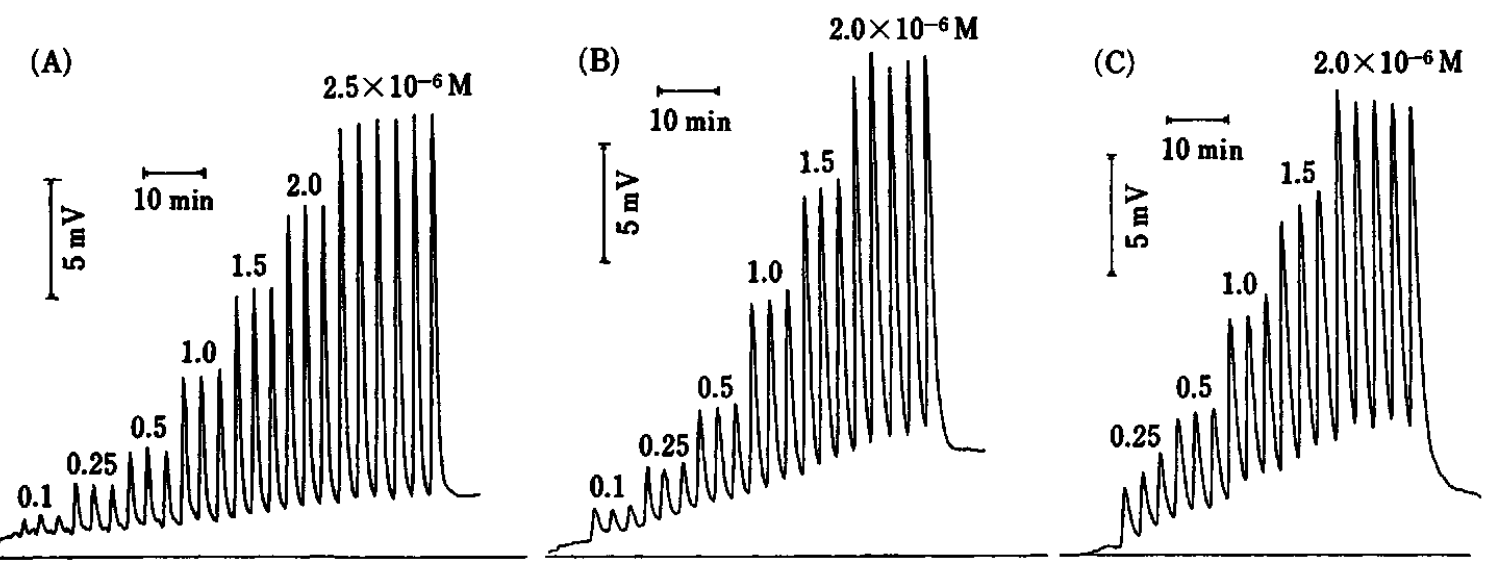

Fig. 3 Reproducibility of potential peaks $v s$. compositions of buffer solutions at low concentrations. Buffer solution (R.S.): (A) $1 \times 10^{-5} \mathrm{M}\left[\mathrm{Fe}(\mathrm{CN})_{6}\right]^{3-}-1 \times 10^{-5} \mathrm{M}\left[\mathrm{Fe}(\mathrm{CN})_{6}\right]^{4-}-0.6 \mathrm{M} \mathrm{NaOH}$; (B) $1 \times 10^{-5} \mathrm{M}\left[\mathrm{Fe}(\mathrm{CN})_{6}\right]^{3-}-1 \times 10^{-6} \mathrm{M}\left[\mathrm{Fe}(\mathrm{CN})_{6}\right]^{4--}-6.6 \mathrm{M} \mathrm{NaOH}$; (C) $5 \times 10^{-6} \mathrm{M}\left[\mathrm{Fe}(\mathrm{CN})_{6}\right]^{3-}-5 \times 10^{-6} \mathrm{M}\left[\mathrm{Fe}(\mathrm{CN})_{6}\right]^{4-}-0.6 \mathrm{M} \mathrm{NaOH}$. Flow condition is shown in Fig. 1 .

successively injected at the interval of $3 \mathrm{~min}$. For $1 \times 10^{-5} \mathrm{M}(1: 1)$ buffer [Fig. 3 (A)], a baseline potential was stable and reproducible, and drifts of potentials were below $0.8 \mathrm{mV} / \mathrm{h}$. Peak heights were proportional to sample concentrations, and the relative standard deviation was $0.9 \%$ for determinations of six samples of $2.5 \times 10^{-6} \mathrm{M}$ glucose. For $1 \times 10^{-5} \mathrm{M}(1: 0.1)$ buffer, i.e., $1 \times 10^{-5} \mathrm{M}\left[\mathrm{Fe}(\mathrm{CN})_{6}\right]^{3-}-1 \times 10^{-6} \mathrm{M}\left[\mathrm{Fe}(\mathrm{CN})_{6}\right]^{4-}$ solution [Fig. 3 (B)], peak heights were almost proportional to sample concentrations. For $1 \times 10^{-6} \mathrm{M}$ glucose sample, the $(1: 0.1)$ buffer solution theoretically should give about 4 times higher potential change than $1 \times 10^{-5} \mathrm{M}(1: 1)$ buffer, but observed peak heights, as shown in Fig. 3(B), were only slightly higher than those in Fig. 3(A). This indicates that the response is not Nernstian for the(1:0.1) buffer solution. For $5 \times 10^{-6} \mathrm{M}$ (1:1) buffer [Fig. 3 (C)], the peak became broad, and peak heights were not reproducible. Thus, the potential buffer consisting of $1 \times 10^{-5} \mathrm{M}\left[\mathrm{Fe}(\mathrm{CN})_{6}\right]^{3-}$ $1 \times 10^{-5} \mathrm{M}\left[\mathrm{Fe}(\mathrm{CN})_{6}\right]^{4-}$ or more concentrated buffers were quite good from both of sensitivity and reproducibility. The lowest detectable concentration was $1 \times 10^{-7} \mathrm{M}$ (peak heights: $0.6 \mathrm{mV}$ ) for $1 \times 10^{-5} \mathrm{M}$ (1:1) buffer. Although nitrogen gas bubbles were used in the gas-segmented flow method ${ }^{8}$ instead of air in order to avoid air-oxidation of $\left[\mathrm{Fe}(\mathrm{CN})_{6}\right]^{4-}$ to $[\mathrm{Fe}-$ $\left.(\mathrm{CN})_{6}\right]^{3-}$ in the buffer stream, the lower limit of detection (at $S / N$ ratio of 3 ) remained $1 \times 10^{-5} \mathrm{M}$.

Excellent sensitivity in the proposed non-gas segmented flow method may be partially due to the high stability of electrode potentials in buffer solutions at low concentrations. When the $1 \times 10^{-5} \mathrm{M}(1: 1)$ buffer was used, FIA peaks for injections at every 2 min were reproducible and agreed with those for injections at every $3 \mathrm{~min}$. Therefore, at least, analysis of $\mathbf{3 0}$ samples/h was possible with high reproducibility by the proposed procedure.
Concludingly, the proposed flow injection analysis for glucose could be more sensitive and rapid than the gas-segmented flow method ${ }^{7,8}$ and may be applicable to separate determination of components of mixed reducing sugars including glucose by combining with high performance liquid chromatography.

\section{References}

1. E. H. Hansen, J. Ruzicka and B. Rietz, Anal. Chim. Acta, 89, 241 (1977).

2. Ch-M. Wolff and H. A. Mottola, Anal. Chem., 50, 94 (1978).

3. C. Ridder, E. H. Hansen and J. Ruzicka, Anal. Lett., 15, 1751 (1982).

4. D. Pilosof and T. A. Nieman, Anal. Chem., 54, 1698 (1982).

5. R. A. Llenado and G. A. Rechnitz, Anal. Chem., 45, 2165 (1973).

6. E. P. Diamandis and T. P. Hadjiioannou, Analyst [London], 107, 1471 (1982).

7. D. G. Porter and R. Sawyer, Analyst [London], 97, 569 (1972).

8. K. Brunt, Analyst [London], 107, 1261 (1982).

9. J. Ruzicka and E. H. Hansen, "Flow Injection Analysis", John Wiley and Sons, New York (1981).

10. H. Ohura, T. Imato, S. Yamasaki and N. Ishibashi, Bunseki Kagaku, 35, 349 (1986).

11. N. Ishibashi and T. Imato, in preparation.

12. N. Ishibashi, T. Imato and T. Masadome, Rep. Asahi Glass Found. Ind. Technol., 47, 23 (1985).

13. N. Nath and M. P. Singh, Z. Phys. Chem., 224, 419 (1963).

14. J. D. Roberts, and M. C. Casserio, "Basic Principles of Organic Chemistry", p. 618, W. A. Benjamin, New York and Amsterdam (1965). 